University of Nebraska - Lincoln

DigitalCommons@University of Nebraska - Lincoln

\title{
Fiber Quality Response of Pima Cotton to Nitrogen and Phosphorus Deficiency
}

Haile Tewolde

Texas A\&M University, htewolde@ars.usda.gov

C. J. Fernandez

Texas A\&M University

Follow this and additional works at: https://digitalcommons.unl.edu/usdaarsfacpub

Part of the Agricultural Science Commons

Tewolde, Haile and Fernandez, C. J., "Fiber Quality Response of Pima Cotton to Nitrogen and Phosphorus Deficiency" (2003). Publications from USDA-ARS / UNL Faculty. 596.

https://digitalcommons.unl.edu/usdaarsfacpub/596

This Article is brought to you for free and open access by the U.S. Department of Agriculture: Agricultural Research Service, Lincoln, Nebraska at DigitalCommons@University of Nebraska - Lincoln. It has been accepted for inclusion in Publications from USDA-ARS / UNL Faculty by an authorized administrator of DigitalCommons@University of Nebraska - Lincoln. 


\title{
Fiber Quality Response of Pima Cotton to Nitrogen and Phosphorus Deficiency
}

\author{
Haile Tewolde $^{*}$ and C. J. Fernandez ${ }^{\dagger}$ \\ Texas A\&M University Agricultural Research \\ and Extension Center, Uvalde, Texas
}

\begin{abstract}
Imposing a moderate level of nutrient deficiency may be an effective management strategy to limit vegetative growth and enhance maturity of Pima cotton (Gossypium barbadense L.). Whether such deficiency affects fiber quality of American Pima cotton, however, is not well known. A field study was conducted in 1991 and 1992 to determine the fiber quality responses of Pima cotton to nitrogen and phosphorus fertilization ranging between deficient and excess. Pima cotton cv. "S-7" was treated with nitrogen rates ranging between 0 and $269 \mathrm{~kg} \mathrm{ha}^{-1}$ in a factorial combination with phosphorus rates ranging between 0 and $44 \mathrm{~kg} \mathrm{ha}^{-1}$. Fiber property measurements included fiber length, strength, fineness, elongation, and color properties. Increasing rate of applied nitrogen significantly $(P \leq 0.05)$ increased fiber length, elongation, micronaire, and color characteristics and reduced fiber uniformity ratio in 1991. Increasing
\end{abstract}

*Correspondence: Haile Tewolde, USDA-ARS, 810 Highway 12 East, Mississippi State, MS 39762-5367, USA. E-mail: htewolde@ars.usda.gov.

${ }^{\dagger}$ Current address: Texas A\&M University Agricultural Research and Extension Center, Route 2, Box 589, Corpus Christi, TX 78406, USA. 
nitrogen rate significantly $(P \leq 0.10)$ increased fiber length, uniformity index, and yellowness in 1992, when the degree of nitrogen deficiency imposed by the lowest nitrogen rate was not as severe as the deficiency imposed by the same treatment in 1991. Phosphorus did not significantly $(P \leq 0.10)$ affect any of the important fiber properties-length, strength, or micronaire - in either cropping season. These results indicate moderate level of nitrogen or phosphorus deficiency does not affect Pima cotton fiber quality. Nitrogen or phosphorus deficiency severe enough to reduce fiber quality and affect marketing of Pima cotton is unlikely to be encountered under normal Pima cotton production practices.

Key Words: Mineral nutrition; Micronaire; Span length.

\section{INTRODUCTION}

Pima cotton (Gossypium barbadense L.) is grown as a source of high quality fiber for manufacturing premium cotton fabrics. It produces longer, stronger, and finer fibers than any Upland cotton variety under production today. The genetic makeup of the Pima cotton plant regulates these fiber traits, but the growing conditions determine whether the quality of the fiber reaches the genetic potential. Mineral nutrition is one of these growing conditions that can affect fiber quality.

In Upland cotton, the effects of nitrogen nutrition on fiber quality have been studied to some degree with fiber length, fineness, and strength being the most extensively studied fiber properties. Many of these studies concluded that nitrogen does not affect any of these fiber quality measurements. ${ }^{[1-4]}$ Murray et al., ${ }^{[3]}$ for example, found no consistent effect on fiber length, strength, or fineness of Upland cotton by nitrogen fertilization that resulted in significant yield responses. They concluded that nitrogen or phosphorus affect cotton production by affecting yield components without affecting fiber properties.

Other studies found that nitrogen nutrition that increases lint yield also increases fiber length implying nitrogen deficiency would reduce fiber length below what may be acceptable for the industry. ${ }^{[5-9]}$ Some of these studies also found that increasing nitrogen nutrition reduces micronaire. ${ }^{[6,10-12]}$

Effect of phosphorus nutrition on fiber quality has been investigated much less than that of nitrogen nutrition. Some early reports indicate that phosphorus affects fiber quality very little. ${ }^{[3,8]}$ Nelson $^{[8]}$ did not find much effect of phosphorus on fiber properties by the same phosphorus rate that increased boll size and lint yield of Upland cotton.

Whether nitrogen or phosphorus nutrition affects fiber quality of Pima cotton is not well documented. An earlier report showed that imposing a 
moderate level of nitrogen deficiency may be an effective management strategy to selectively limit vegetative growth and enhance maturity of Pima cotton. ${ }^{[13,14]}$ Because the value of Pima cotton depends on producing high quality fiber, whether such deficiency of nitrogen or phosphorus nutrition affects its fiber properties needs to be established. The objective of this study was to determine the fiber quality responses of Pima cotton to nitrogen and phosphorus fertilization ranging from deficient to excess. This was part of a larger study in which the maturity-enhancing effects of nitrogen and phosphorus deficiencies were tested under field conditions.

\section{MATERIALS AND METHODS}

The study was conducted at the Texas A\&M University Agricultural Research and Extension Center, Uvalde, TX in a Uvalde silty clay loam soil in 1991 and 1992. Pima cotton cv. "S-7" was planted on 28 March 1991 and 15 April 1992 in plots comprising six 15.2-m-long rows spaced $0.97 \mathrm{~m}$ apart. Treatments included applied rates of $0,67,135,202$, and $269 \mathrm{~kg} \mathrm{Nha}^{-1}$ in a factorial combination with $0,15,29$, and $44 \mathrm{~kg} \mathrm{P}^{-1}$. Urea $(45-0-0 \mathrm{~N}-\mathrm{P}-\mathrm{K})$ as the source of $\mathrm{N}$ and triple superphosphate $(0-46-0)$ as the source of $\mathrm{P}$ were broadcast and incorporated $1-4 \mathrm{~d}$ before planting. The test was conducted in randomized complete block design with four replications.

Plots used in 1991 were the same plots where the response of corn (Zea mays L.) to the same levels of $\mathrm{N}$ and $\mathrm{P}$ as described above in this present study had been tested continuously between 1986 and 1990. Thus, the no-nitrogen and no-phosphorus plots in 1991 were expected to be severely depleted of these nutrients; whereas, accumulation of both $\mathrm{N}$ and $\mathrm{P}$ was expected in plots that received high $\mathrm{N}$ and $\mathrm{P}$ rates. The 1992 test was conducted in a field that had been fertilized with $135 \mathrm{~kg} \mathrm{Nha}^{-1}$ and $29 \mathrm{~kg} \mathrm{P} \mathrm{ha}^{-1}$ and planted to wheat (Triticum aestivum L.) in 1990 and then planted to corn in 1991 without fertilization to deplete residual nutrients. Relative levels of residual $\mathrm{N}$ were expected to range between low and high in 1991 (depending on the treatment in the corn study) and to be moderately low and more uniform across plots in 1992. Measurement of residual soil $\mathrm{NO}_{3}-\mathrm{N}$ content confirmed that the N-0 plots had low N levels in 1991. However, the cumulative effect of high $\mathrm{N}$ treatments during the previous five seasons on residual $\mathrm{NO}_{3}-\mathrm{N}$ was small: $22.0 \mathrm{~kg} \mathrm{ha}^{-1}$ for the $135 \mathrm{~kg} \mathrm{Nha}^{-1}$ plots and $27.2 \mathrm{~kg} \mathrm{ha}^{-1}$ for the $269 \mathrm{~kg} \mathrm{Nha}^{-1}$ plots compared to less than $15.8 \mathrm{~kg} \mathrm{ha}^{-1}$ for the $0 \mathrm{~kg} \mathrm{Nha}^{-1}$ plots in the top $0.91 \mathrm{~m}$ profile. Residual soil $\mathrm{NO}_{3}-\mathrm{N}$ in 1992 was also uniformly low in all plots $\left(<14.4 \mathrm{~kg} \mathrm{ha}^{-1}\right)$. Additional description of cultural practices is provided elsewhere. ${ }^{[14]}$ 
Fiber quality measurements were made on first- or second-position boll samples hand-picked $\approx 5$ days before harvest. Measurements in the first year included 2.5 and $50 \%$ span length, uniformity ratio (UR, which is the ratio of $50 \%$ to $2.5 \%$ span length), micronaire as a measure of fiber fineness and maturity, strength, elongation, and fiber color parameters. These measurements were made with individual instrumentation at the laboratory of the USDA-ARS Pima cotton breeding and genetics program at Maricopa Agricultural Center, Maricopa, AZ as described by Percy and Turcotte. ${ }^{[15]}$ Fiber quality measurements in the second season included length, uniformity index (which is the ratio of mean length of all fibers divided by the mean length of the longest one-half fibers in a sample as a \%), micronaire, strength, elongation, and color parameters measured by high volume instrumentation (HVI). All measurements in the second season were made at the International Center for Textile Research and Development, Texas Tech University, Lubbock, TX.

The data were subjected to analysis of variance and orthogonal polynomial tests up to the third degree performed on both nitrogen and phosphorus. Nitrogen data are presented as averages across all phosphorus levels, and phosphorus data also are presented as averages across all nitrogen levels. Significant interactions between nitrogen and phosphorus occurred only rarely. All differences declared significant were at the $P \leq 0.05$ probability level unless specified otherwise.

\section{RESULTS AND DISCUSSION}

\section{Season}

All nitrogen treatments produced micronaire values acceptable for the industry without discounts. However, micronaire was significantly affected by applied nitrogen. Increasing nitrogen rate resulted in a small but a highly significant linear increase of micronaire (Table 1), a response that contrasts the response of Upland cotton. ${ }^{[6,10-12]}$ Ebelhar et al. ${ }^{[10]}$ showed that micronaire of Upland cotton cv. "DES-119" decreased as nitrogen rate increased between 101 and $202 \mathrm{~kg} \mathrm{Nha}^{-1}$. Hearn ${ }^{[6]}$ also reported heavy nitrogen application (225 vs. $34 \mathrm{~kg} \mathrm{Nha}^{-1}$ ) decreased micronaire of two Upland cultivars, "Acala 1517 BRI" and "Deltapine 16", with greater decrease in Deltapine 16 than in Acala 1517.

Nitrogen had a significant quadratic effect on $2.5 \%$ span length. Span length (2.5\%), which approximates classer's staple length, is the length spanned by the longest $2.5 \%$ fibers held at one end by a clamp. 


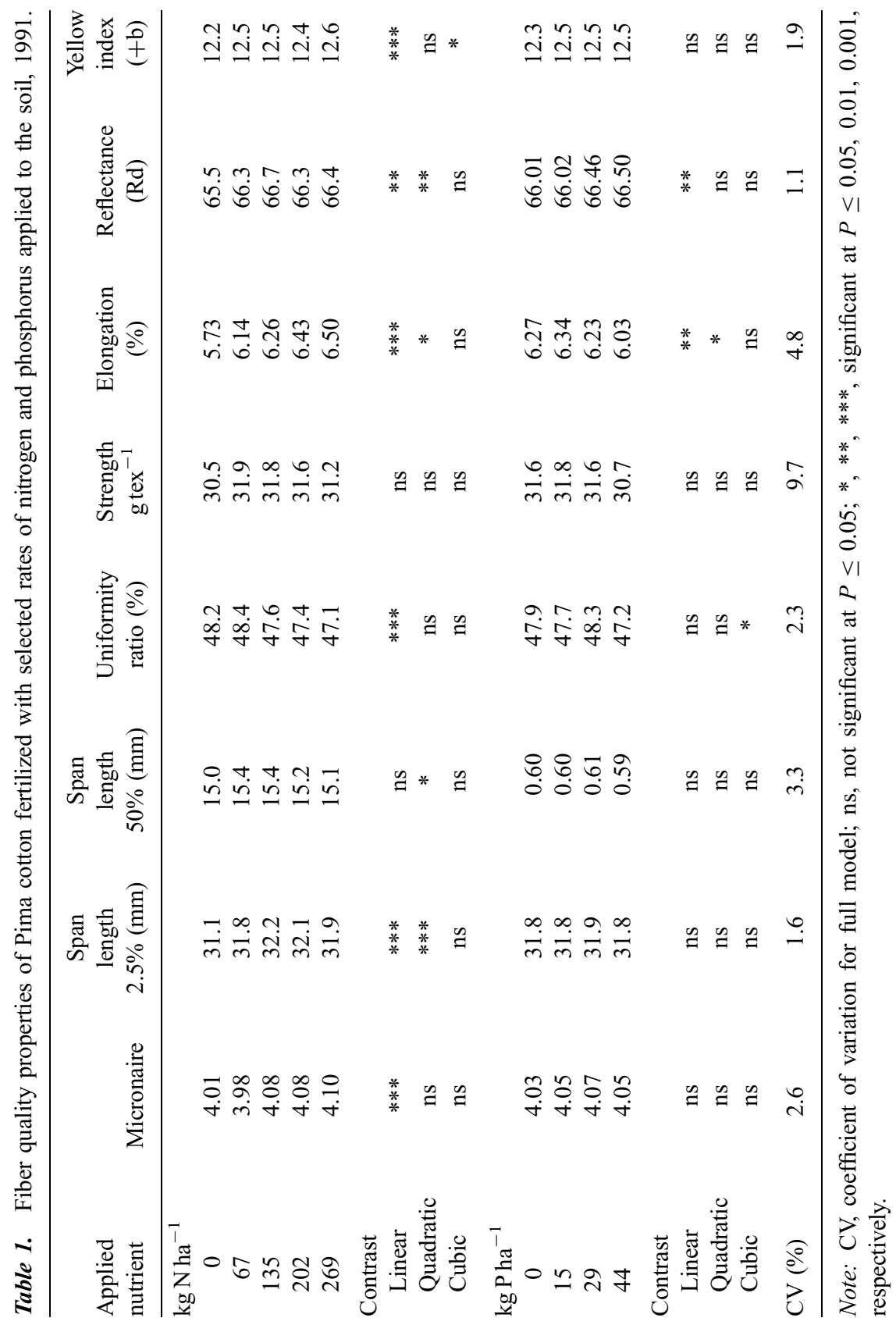


The $2.5 \%$ span length increased with increasing applied nitrogen up to $135 \mathrm{~kg} \mathrm{Nha}^{-1}$ and slightly decreased with additional applied nitrogen (Table 1). The most severely nitrogen-deficient plants $\left(0 \mathrm{~kg} \mathrm{~N} \mathrm{ha}^{-1}\right)$ produced $1.1 \mathrm{~mm}$ shorter fibers than plants that received $135 \mathrm{~kg} \mathrm{Nha}^{-1}$. Plants that received the highest nitrogen rate $\left(269 \mathrm{~kg} \mathrm{Nha}^{-1}\right)$ produced slightly shorter fibers than plants that received $135 \mathrm{~kg} \mathrm{Nha}^{-1}$. Wadleigh ${ }^{[5]}$ reported similar results with container-grown Upland cotton. Perkins and Douglas ${ }^{[9]}$ also reported that upper half mean length of Upland cotton increased from $27.2 \mathrm{~mm}$ with no nitrogen to $28.7 \mathrm{~mm}$ with $34 \mathrm{~kg} \mathrm{~N} \mathrm{ha}^{-1}$. Additional nitrogen application beyond $34 \mathrm{~kg} \mathrm{Nha}^{-1}$ up to $236 \mathrm{~kg} \mathrm{Nha}^{-1}$ did not have additional effects on fiber length. Our findings on Pima cotton and those reported for Upland cotton confirm that nitrogen in excess of a certain level does not necessarily result in the longest fibers. Just as in yield, there seems to be an optimum nitrogen rate that results in the longest fibers. Ramey ${ }^{[16]}$ discussed that growth conditions that are optimum for lint yield are also optimum for fiber length.

Nitrogen had also a significant quadratic effect on $50 \%$ span length with 0 and $269 \mathrm{~kg} \mathrm{Nha}^{-1}$ rates producing the shortest $50 \%$ span length. Uniformity ratio, which is the ratio of $50 \%$ span length to $2.5 \%$ span length, decreased significantly as the rate of applied nitrogen increased. This indicates high rates of applied nitrogen result in less uniform fibers.

Nitrogen did not significantly affect fiber strength, a property that directly affects yarn strength (Table 1). The most nitrogen-deficient plants $\left(0 \mathrm{~kg} \mathrm{Nha}^{-1}\right)$ produced the weakest fibers at $30.5 \mathrm{~g} \mathrm{tex}^{-1}$, but this strength value was not significantly less than the value of the other treatments. All other nitrogen treatments produced fibers of equivalent strength although the same treatments significantly affected micronaire. Ebelhar et al. ${ }^{[10]}$ also found nitrogen rates that significantly affected micronaire failed to affect fiber strength. Our finding and that of Ebelhar et al. ${ }^{[10]}$ do not seem to be consistent with the view that fiber strength is a direct function of fiber wall thickness. ${ }^{[16]}$

Fiber elongation increased with increasing applied nitrogen up to the maximum rate of $269 \mathrm{~kg} \mathrm{Nha}^{-1}$. Fiber elongation is the degree of fiber extension (\%) at the point of break while force is applied to fibers when measuring strength. Ramey ${ }^{[16]}$ believes greater fiber elongation is an indication of less secondary wall deposition. Our results indicate nitrogen is necessary for greater Pima cotton fiber elongation, a property that may affect the frequency of yarn breakage during spinning. ${ }^{[17]}$

Nitrogen significantly affected fiber color characteristics. Reflectance degree $(\mathrm{Rd})$ was lowest with the most severe nitrogen treatment $\left(0 \mathrm{~kg} \mathrm{~N} \mathrm{ha}^{-1}\right)$. This means fibers produced by the most nitrogen-deficient plants appeared less bright than fibers produced by nitrogen-sufficient plants. The yellow index was 
also lowest with the most nitrogen-deficient plants. Both color measurements suggest that the $0 \mathrm{~kg} \mathrm{~N}^{-1}$ treatment, which was an extremely severe nitrogen treatment, resulted in less desirable fiber color characteristics.

Nitrogen did not affect the number of mature seeds each boll produced, but increasing rates of nitrogen resulted in a significant quadratic increase of individual seed weight (Table 2). The amount of lint each seed produced also increased as nitrogen rate increased. Lint weight as a \% of the seed cotton weight, however, decreased as nitrogen rate increased. The decrease in lint weight is because nitrogen increased seed weight more than it increased lint weight, a $13.9 \%$ increase for seed vs. only $7.7 \%$ increase for lint,

Table 2. Seed and lint characteristics of Pima cotton treated with selected rates of nitrogen and phosphorus applied to the soil, 1991.

\begin{tabular}{|c|c|c|c|c|}
\hline $\begin{array}{l}\text { Applied } \\
\text { nutrient }\end{array}$ & $\begin{array}{c}\text { Seeds } \\
\left(\text { no. boll }{ }^{-1}\right)\end{array}$ & $\begin{array}{c}\text { Seed } \\
\text { weight } \\
\left(\mathrm{mg} \mathrm{seed}^{-1}\right)\end{array}$ & $\begin{array}{c}\text { Lint } \\
\text { weight } \\
\left(\mathrm{mg} \mathrm{seed}^{-1}\right)\end{array}$ & $\begin{array}{l}\text { Lint } \\
\text { turnout } \\
(\%)\end{array}$ \\
\hline \multicolumn{5}{|l|}{$\mathrm{kgNha}^{-1}$} \\
\hline 0 & 15.3 & 101 & 60.0 & 37.2 \\
\hline 67 & 15.6 & 107 & 62.4 & 36.9 \\
\hline 135 & 15.6 & 112 & 63.2 & 36.1 \\
\hline 202 & 15.9 & 113 & 64.1 & 36.2 \\
\hline 269 & 15.6 & 115 & 64.6 & 36.0 \\
\hline \multicolumn{5}{|l|}{ Contrast } \\
\hline Linear & $\mathrm{ns}$ & $* * *$ & $* * *$ & $* * *$ \\
\hline Quadratic & $\mathrm{ns}$ & $* *$ & $\mathrm{~ns}$ & $\mathrm{~ns}$ \\
\hline Cubic & ns & ns & ns & ns \\
\hline \multicolumn{5}{|l|}{$\mathrm{kgPha}^{-1}$} \\
\hline 0 & 15.5 & 106 & 61.6 & 36.9 \\
\hline 15 & 15.2 & 109 & 63.5 & 36.7 \\
\hline 29 & 16.1 & 111 & 63.1 & 36.4 \\
\hline 44 & 15.6 & 113 & 63.2 & 36.0 \\
\hline \multicolumn{5}{|l|}{ Contrast } \\
\hline Linear & $\mathrm{ns}$ & $* * *$ & ns & $* * *$ \\
\hline Quadratic & ns & $\mathrm{ns}$ & $\mathrm{ns}$ & $\mathrm{ns}$ \\
\hline Cubic & $*$ & ns & ns & $\mathrm{ns}$ \\
\hline CV (\%) & 6.9 & 3.4 & 4.2 & 2.4 \\
\hline
\end{tabular}

Note: $\mathrm{CV}$, coefficient of variation for full model; ns, not significant at $P \leq 0.05$; *,**, ***, significant at $P \leq 0.05,0.01,0.001$, respectively. 
comparing the 0 and $269 \mathrm{~kg} \mathrm{Nha}^{-1}$ treatments (Table 2). Decreasing lint turnout is the most consistently reported response of Upland cotton to increasing rate of applied nitrogen. ${ }^{[1,4,5,8,18]}$

Applied phosphorus did not affect fiber length (2.5 or 50\% span length), strength, or micronaire (Table 1) despite its yield and growth reducing effects. ${ }^{[13,14]}$ But phosphorus significantly affected elongation, reflectance, individual seed weight, and lint turnout (Tables 1 and 2). Fiber elongation decreased with increasing applied phosphorus. Reflectance increased slightly but significantly with increasing applied phosphorus. The effect of phosphorus on seed weight and lint turnout was similar to that of nitrogen. Increasing applied phosphorus increased seed weight but reduced lint turnout (Table 2).

Fiber length, micronaire, and the amount of lint produced per seed showed strong correlation with seed size. Larger seeds produced longer fibers with greater micronaire than smaller seeds (Figs. 1 and 2). Because cotton fibers develop from epidermal cells of the ovule, the amount of lint produced per seed should depend on the size of the fully mature seed. Figure 3 shows a close relationship between seed weight and the amount of lint a seed produces. This relationship implies factors that limit growth and development of the seed should limit the amount of lint produced as well as fiber length and fineness. The lint yield reducing effect of

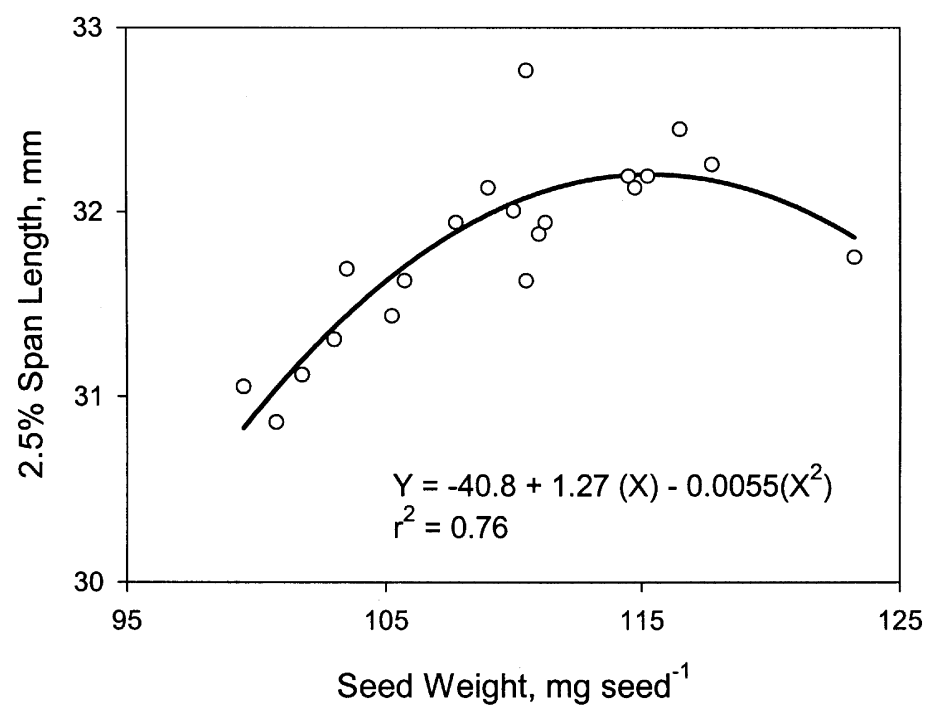

Figure 1. Relationship between 2.5\% span length and seed weight of Pima cotton fertilized with selected rates of nitrogen and phosphorus in 1991. Seed weight variations were largely due to varying rates of nitrogen. 


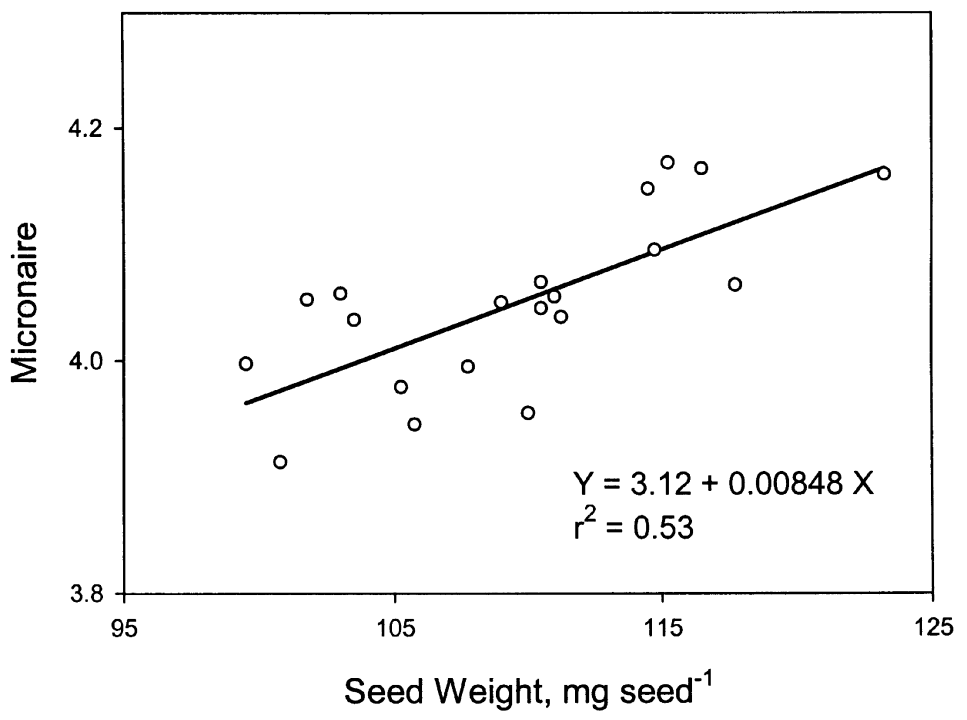

Figure 2. Relationship between micronaire and seed weight of Pima cotton fertilized with selected rates of nitrogen and phosphorus in 1991. Seed weight variations were largely due to varying rates of nitrogen.

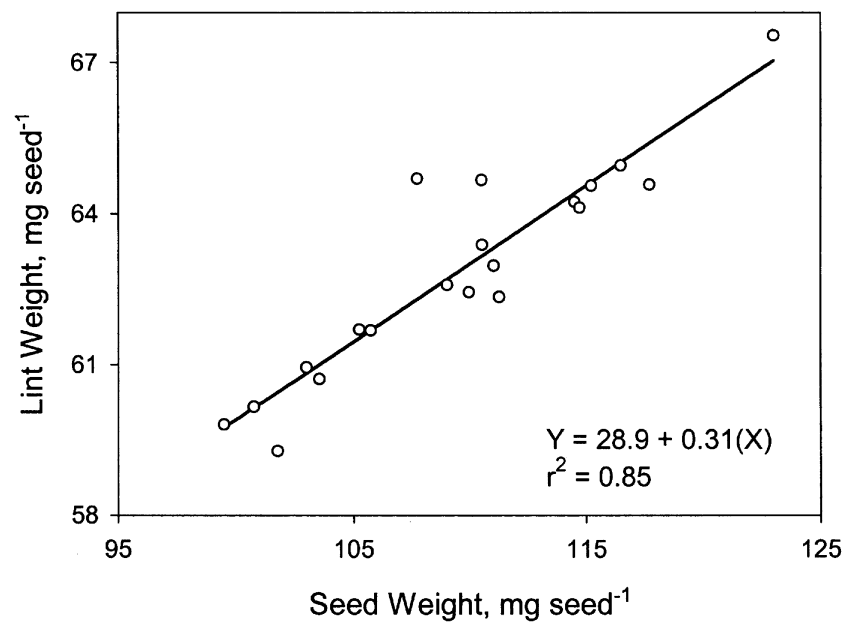

Figure 3. Relationship between lint weight and seed weight of Pima cotton fertilized with selected rates of nitrogen and phosphorus in 1991. Seed weight variations were largely due to varying rates of nitrogen. 
nitrogen deficiency therefore may not be the result of its direct effect on lint growth but a result of its effect on seed growth in addition to its effect on boll size and number of bolls per plant. ${ }^{[13]}$ Hearn $^{[18]}$ stated that nitrogen rate affected weight and number of seeds more than weight of lint per seed in Upland cotton. In our study with Pima cotton, the number of seeds per boll was not affected even by the most severe nitrogen deficiency (Table 2).

\section{Season}

Applied nitrogen or phosphorus in 1992 did not affect fiber quality as much as in 1991. Nitrogen in 1992 slightly increased HVI fiber length, uniformity index, and yellowness but did not significantly affect micronaire, elongation, or reflectance (Table 3 ). It had a significant quadratic effect on fiber yellowness, with the most nitrogen-deficient plants producing fibers with less yellowness. The slight linear increases in fiber length and uniformity index with increasing rate of nitrogen were significant only at the $10 \%$ probability level. Phosphorus did not affect any fiber properties in 1992.

The small effect of nitrogen or the lack of effect of phosphorus on fiber quality in 1992 may be because the degree of deficiency imposed by the lowest nutrient rates in 1992 was not as severe as the deficiency imposed by the same treatments in 1991. Murray et al. ${ }^{[3]}$ reported that nitrogen or phosphorus rates that resulted in lint yield responses of Upland cotton did not result in consistent fiber quality responses. They speculated that, once the cotton plant receives a certain minimum level of nitrogen or phosphorus nutrition, fiber quality is determined by factors other than these nutrients. It is likely plants treated with the lowest $\mathrm{N}$ rate in our study in 1992 received adequate residual nitrogen to produce lint with fiber properties comparable to plants that received higher nitrogen rates.

\section{CONCLUSIONS}

We tested the effect of nitrogen and phosphorus rates ranging between deficient and excess on fiber properties of American Pima cotton. Nitrogen significantly affected fiber quality during both seasons with a more pronounced effect on fiber quality in 1991 than in 1992. However, fiber quality reductions that result in price discounts may only occur with nitrogen deficiency as severe as the $0 \mathrm{kgNha}^{-1}$ treatment of 1991. Because this treatment was under continuous corn for $5 \mathrm{yr}$ with no nitrogen fertilization, it is unlikely to encounter nitrogen deficiency of that severity under normal 


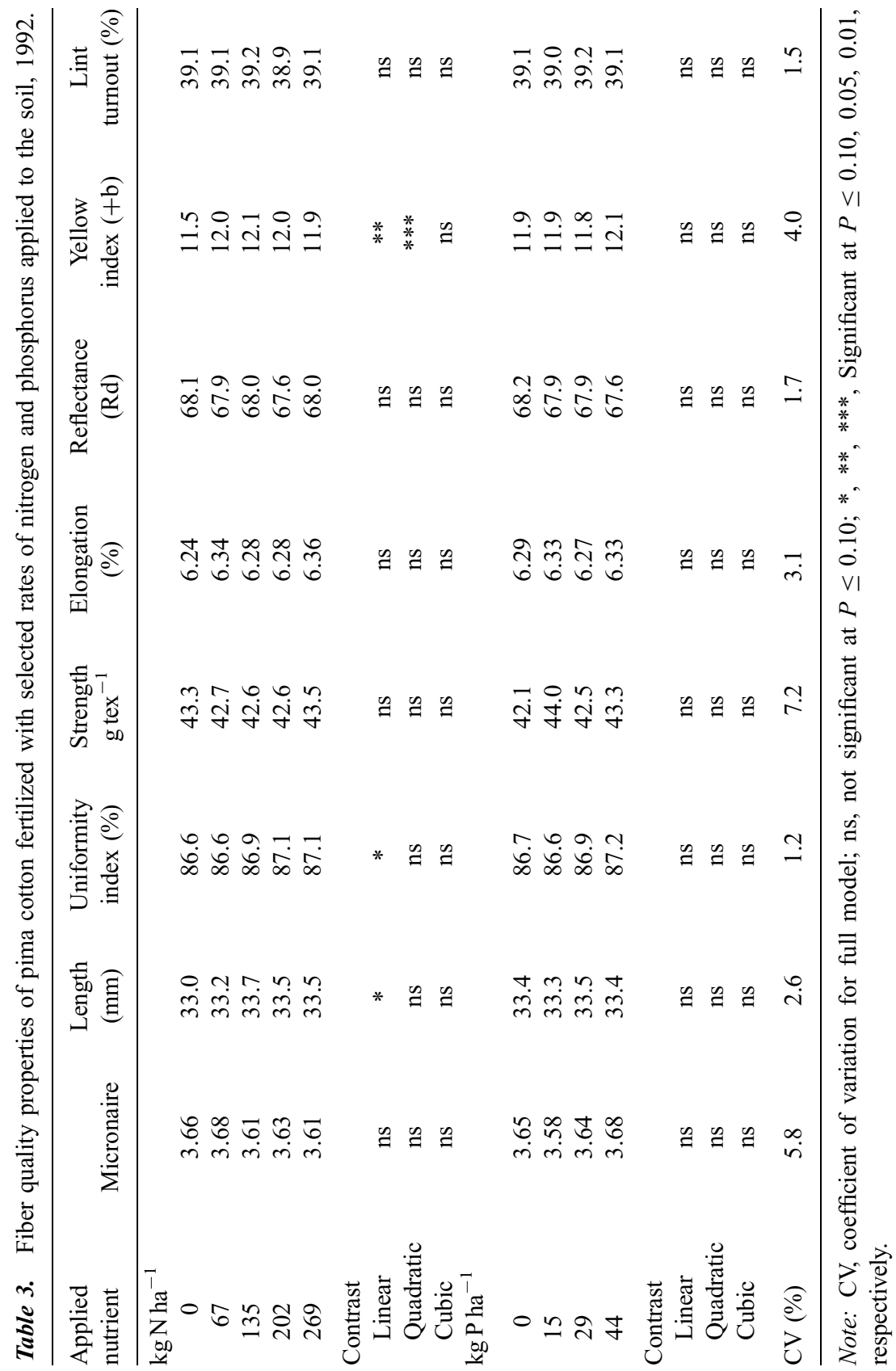


Pima cotton production practices. Moderate nitrogen deficiency equivalent to that of the $67 \mathrm{~kg} \mathrm{Nha}^{-1}$ treatment may not affect fiber quality that results in discounts. Imposing a moderate level of nitrogen deficiency as a management strategy to selectively suppress excessive vegetative growth and enhance maturity as discussed by Tewolde et al. ${ }^{[13]}$ may therefore be a plausible practice without affecting the quality of the fiber produced.

\section{REFERENCES}

1. Boman, R.K.; Westerman, R.L. Nitrogen and mepiquat chloride effects on the production of nonrank, irrigated, short-season cotton. J. Prod. Agric. 1994, 7, 70-75.

2. MacKenzie, A.J.; van Schaik, P.H. Effect of nitrogen on yield, boll, and fiber properties of four varieties of irrigated cotton. Agron. J. 1963, 55, 345-347.

3. Murray, J.C.; Reed, R.M.; Oswalt, E.S. Effect of fertilizer treatments on the fiber properties of cotton. Agron. J. 1965, 57, 227.

4. Grimes, D.W.; Dickens, W.L.; Anderson, W.D. Functions for cotton (Gossypium hirsutum L.) production from irrigation and nitrogen fertilization variables: II. Yield components and quality characteristics. Agron. J. 1969, 61, 773-776.

5. Wadleigh, C.H. Growth Status of the Cotton Plant as Influenced by the Supply of Nitrogen; Ark. Agric. Exp. Stn.: Fayetteville, AR, 1944; Bull. 446.

6. Hearn, A.B. Response of cotton to nitrogen and water in a tropical environment. III. Fiber quality. J. Agric. Sci., Camb. 1976, 86, 257-269.

7. Constable, G.A.; Hearn, A.B. Irrigation for crops in a sub-humid environment. VI. Effect of irrigation and nitrogen fertilizer on growth, yield and quality of cotton. Irrig. Sci. 1981, 3, 17-28.

8. Nelson, W.L. The effect of nitrogen, phosphorus, and potash on certain lint and seed properties of cotton. Agron. J. 1949, 41, 289-293.

9. Perkins, H.F.; Douglas, A.G. Effects of nitrogen on the yield and certain properties of cotton. Agron. J. 1965, 57, 383-384.

10. Ebelhar, M.W.; Welch, R.A; Meredith, W.R. Nitrogen rates and mepiquat chloride effects on cotton lint yield and quality. In Proceedings of the Beltwide Cotton Conferences, 1996; Dugger, P; Richter, D., Eds.; National Cotton Council: Memphis, TN, USA, 1996; 1373-1378.

11. Koli, S.E.; Morrill, L.G. Effects of narrow row, plant population, and nitrogen application on cotton fiber characteristics. Agron. J. 1976, 68, 794-797. 
12. Rochester, I.J.; Peoples, M.B.; Constable, G.A. Estimation of the $\mathrm{N}$ fertilizer requirement of cotton grown after legume crops. Field Crops Res. 2001, 70, 43-53.

13. Tewolde, H.; Fernandez, C.J.; Foss, D.C. Maturity and lint yield of nitrogen- and phosphorus-deficient Pima cotton. Agron. J. 1994, 86, 303-309.

14. Tewolde, H.; Fernandez, C.J. Vegetative and reproductive dry weight inhibition in nitrogen- and phosphorus-deficient Pima cotton. J. Plant Nutr. 1997, 20, 219-232.

15. Percy, R.G.; Turcotte, E.L. Interspecific hybrid fiber characteristics of cotton altered by unconventional Gossypium barbadense L. fiber genotypes. Crop Sci. 1992, 32, 1437-1441.

16. Ramey H.H. Jr. Stress influences on fiber development. In Cotton Physiology; Mauney, J.R., Stewart, J. Eds.; The Cotton Foundation: Memphis, 1986; 351-359.

17. Waters, W.T.; Phillips, J.; Fiori, L.A. The effect of fiber-bundle elongation of medium staple cottons on processing performance and yarn properties. Textile Res. J. 1966, 36, 1004-1012.

18. Hearn, A.B. Response of cotton to water and nitrogen in a tropical environment. II. Date of last watering and rate of application of nitrogen fertilizer. J. Agric. Sci., Camb. 1975, 84, 419-430. 